\title{
Ludzie (z) Nowej Huty. O dwóch filmach Kazimierza Karabasza
}

\author{
PIOTR ZWIERZCHOWSKI
}

Uniwersytet Kazimierza Wielkiego

1.

Nowa Huta wielokrotnie stawała się bohaterem kronik filmowych, dokumentów i filmów fabularnych[1]. W centrum uwagi filmowców znajdowały się idee, budowle, architektura, historia, teraźniejszość, ludzie, przemysł, w zależności od artystycznych założeń, propagandowych zamierzeń, czasu realizacji. Dziesiątki tysięcy metrów taśmy poświęciła Nowej Hucie Polska Kronika Filmowa, towarzysząc jej powstawaniu od samego początku. W tym czasie kino jedynie sławiło sztandarową budowę socjalizmu, przede wszystkim w filmach dokumentalnych, jak Kierunek - Nowa Huta Andrzeja Munka czy Na wielkiej budowie Romana Banacha, ale budowa Nowej Huty stała się także scenerią socrealistycznej fabuły Trzy opowieści Czesława Petelskiego, Konrada Nałęckiego i Ewy Poleskiej.

W kolejnych latach pojawiały się filmy, które podchodziły do Nowej Huty o wiele bardziej krytycznie. Już w roku 1957 dokumentalne Miejsce zamieszkania Maksymiliana Wrocławskiego i fabularne Zagubione uczucia Jerzego Zarzyckiego odkłamywały socrealistyczną propagandę, ukazując, dwa lata po Poemacie dla dorosłych Adama Ważyka, mroczne oblicze budowy Nowej Huty. Najbardziej znanym filmem, demitologizującym okres Narodzin miasta, by użyć tytułu dokumentu Jana Łomnickiego (1959), jest oczywiście Człowiek z marmuru (1976) Andrzeja Wajdy, ukazujący socjalizm jako eksperyment, którego jednym z symbolicznych początków była budowa Nowej Huty, i który znalazł równie symboliczne podsumowanie na ulicach Gdańska w grudniu 1970 roku.

Filmów, które rejestrowały rzeczywistość Nowej Huty bądź wykorzystywały ją w różny sposób jako symbol socjalistycznej Polski, było rzecz jasna więcej, by wspomnieć Budowałem miasto (1972) Bohdana Kosińskiego, Były tam (1985) Danuty Halladin czy Papieros od prezydenta (1987) Grzegorza Kwinty, filmy Jana Łomnickiego i Jerzego Ridana. Wśród nich znajdują się dwa bardzo skromne filmy Kazimierza Karabasza: Cień już niedaleko (1984) i Pamięć (1985). Nie należą one do najbardziej znanych filmów o Nowej Hucie, nie ujawniają nieznanych faktów z jej dziejów, co więcej - według twórcy sama Nowa Huta nie gra w tych filmach pierwszoplanowej roli.

Karabasz pisał o swoich pełnometrażowych dokumentach: Próbie materii (1981) i Pamięci (1985), że próbowały one

[...] wyjść poza konkret określonego „tematu”, szerzej niż relacja ze zdarzenia czy życiorysu. To były próby stworzenia filmów o pewnych „sprawach”, a warszawska Wola czy Nowa Huta były tylko pretekstami...[2]

Karabasz, podobnie jak Bohdan Kosiński[3] w odniesieniu do głośnego filmu Budowałem miasto z roku 1972[4], sugeruje, że Nowa Huta jest dla niego nieważna, a miejsce wyboru życia bohaterów ma w gruncie rzeczy drugorzędne znaczenie. Dlaczego jednak w takim razie Kosiński i Karabasz wybrali Nową Hutę? Dlacze-

[1] Por. Etap: Nowa Huta. Festiwal Filmowy. Katalog filmów fabularnych, dokumentalnych, reportaży oraz innych materiatów filmowych o Nowej Hucie, Kraków 1999.

[2] K. Karabasz, Odczytać czas, PWSFTviT, Łódź 1999, s. 65.

[3] Nowa Huta i Kraków. Rozmowa z Bohdanem Kosińskim, rozmawiał R. Grzela, oprac. B. Janicka, w: Chetmska 21. 50 lat Wytwórni Filmów Dokumentalnych i Fabularnych $w$ Warszawie, red. B. Janicka, A. Kołodyński, WFDiF, Warszawa [200o], s. 151.

[4] Warto zauważyć, że oba filmy montowała Lidia Zonn. 
go akurat Nowa Huta okazała się doskonałym „pretekstem”, aby powiedzieć o czymś więcej? Mimo wszystko, nie przypadkiem to właśnie miejsce stało się przestrzenią życia bohaterów i filmów Kazimierza Karabasza.

Autor Muzykantów rzadko sięgał po fabułę, dlatego też fakt, że uczynił to, opisując Nową Hutę, w dodatku kręcąc również dokument, wydaje się znaczący. Wszyscy recenzenci podkreślali wiarygodność i autentyczność Cienia..., zwracając uwage na dorobek i doświadczenie dokumentalisty. Sam Karabasz traktował oba filmy jako dopełniające się. Sięgnął po fabułę, żeby zderzyć się z losem jednostkowym:

Kiedy w dokumencie odtwarza się los zbiorowy, odczuwa się niedosyt doświadczeń i racji jednostkowych, indywidualnych[5].

Od budowy Nowej Huty minęło kilkadziesiąt lat. Pamięć wynikała $\mathrm{z}$ chęci zapisania losów ludzi, którzy zaczęli już odchodzić. Chodziło także o utrwalenie ich wspomnień. Kazimierz Karabasz mówił, że Pamięć

[...] ma być zbiorowym portretem pokolenia budowniczych Nowej Huty. Co w nich pozostało z dawnego poświęcenia, ofiarności, pasji, optymizmu i marzeń, czy są to ludzie zawiedzeni, zgorzkniali czy nie?[6]

Czy z tych filmów wyłania się prawda o Nowej Hucie, o kombinacie, opłacalności ekonomicznej, warunkach życia robotników, miejscu partii i organizacji młodzieżowych, junakach ze Służby Polsce? Jak napisał Władysław Cybulski,

okazja rocznicowa na ekranie pozwala wrócić w przeszłość, ale takie powroty bywają niebezpieczne: nie da się wskrzesić dawnych, wspólnych emocji, a i spotkanie z echami młodości straciło blask[7].

W Pamięci inżynierowie, nauczyciele, pracownicy stołówki, funkcjonariusze milicji

[5] Dwa spojrzenia na Nowa Hutę. Rozmowa

z Kazimierzem Karabaszem, rozmawiał B. Zagro-

ba, „Film” 1984, nr 30, s. 2.

[6] Cień już niedaleko, „Filmowy Serwis Praso-

wy" 1985 , nr 14, s. 6.

[7] W. Cybulski, „Cień już niedaleko”, „Dziennik Polski” 1985, nr 278. wspominają obyczajowość, zderzenie obietnic i faktów. W ich wypowiedziach pojawiają się zobowiązania produkcyjne i przekraczanie norm, entuzjazm, praca jako wartość, duma z dobrze wykonanej pracy, godność robotnika, odpowiedzialność, ale i opóźnienia, zmęczenie, które zwalało z nóg, dezercje, brak dyscypliny, głód, wszechobecny smród, wybuchające epidemie, zagrożenie tyfusem. W połowie lat 80 . podobne zestawienia, które można by mnożyć, nie były już niczym szczególnie odkrywczym. Wokół budowy Nowej Huty stworzono konsekwentnie przemyślaną mitologię, ale robotnicy mogli ją zweryfikować nadzwyczaj szybko. Realia budowy różniły się w sposób oczywisty od wizerunku prezentowanego w oficjalnych tekstach, czego świadectwo dał Adam Ważyk w Poemacie dla dorosłych, jak również Jerzy Zarzycki w Zagubionych uczuciach, a prawie dwadzieścia lat później Andrzej Wajda w Człowieku $z$ marmuru.

Na Cień już niedaleko, opowieść o starym robotniku, który po latach przyjeżdża do Nowej Huty odebrać odznaczenie z okazji jubileuszu pierwszego spustu surówki z wielkiego pieca, można spojrzeć jako na uniwersalny film o próbie starzenia się z godnością. Nowohucki jubileusz jest jedynie pretekstem, aby zapytać o sens życia starego człowieka. Czy zatem Nowa Huta jako pewien byt społeczny, element socjalistycznej propagandy, niknie $\mathrm{z}$ pola zainteresowania Karabasza, stanowiąc zaledwie tło? Oczywiście, nie. Film Karabasza jest portretem specyficznego miejsca, gdzie starość i młodość stają się zarazem symbolem pokoleń. Przemiany społeczne i obyczajowe są przecież zawsze tłem jego filmów. Karabasz portretuje ludzi, nie miejsca, ale są to zawsze ludzie żyjący w określonym czasie i przestrzeni życia. Tą przestrzenią jest w przypadku $\mathrm{Pa}$ mięci i Cień już niedaleko Nowa Huta. Oczywiście, jest ona przypisana tym konkretnym bohaterom, ale chodzi też o to, że stała się ona symbolem pokolenia, miejscem znaczącym w polskiej przestrzeni symbolicznej czasów Polski Ludowej. Dlatego też nigdy nie będzie neutralna znaczeniowo. 
2.

Realizując dwa filmy, których akcja rozgrywa się w Nowej Hucie, Karabasz cały czas pozostaje w kręgu tematów, które były mu bliskie od dawna. Reżyser konsekwentnie powracał do tematyki robotniczej. Kilka ważnych filmów poświęcił ludziom wchodzącym w świat dorosłych, choćby Rok Franka W. czy też Na progu. W dorobku Karabasza znajdziemy także filmy o ludziach starych, czego znakomitym przykładem są $M u$ zykanci. Najważniejsze kwestie, które podejmuje Karabasz, obecne także w filmach nowohuckich, to nieustanny - niezależnie od czasu - styk tego, co prywatne, z tym, co oficjalne, jak również różnice $\mathrm{w}$ doświadczeniu pokoleń.

Małgorzata Hendrykowska, opisując Widok $z$ huty (1990) Kazimierza Karabasza, pełnometrażowy film dokumentalny poświęcony ludziom z chorzowskiej huty „Batory”, który powstał na przełomie lat 8o. i 9o., wskazuje na obecność w tym filmie bohatera typowego dla Karabasza,

[...] takiego, który przez swoją zwyczajność, potoczność doświadczenia, powie nam dużo więcej o rzeczywistości niż dziesiątki opracowań szczegółowych. Karabasza interesuje już nie tylko portret mikrospołeczności jak w Muzykantach [1960], Ludziach $w$ drodze [1960], Ptakach [1963] czy w Punkcie widzenia [1973], nie tylko studium jednostki jak w Roku Franka W. [1967] czy Krystynie M. [1973]. Od pewnego momentu znacznie ciekawsza wydaje mu się - jak sądzę - konfrontacja postaw wobec życia przedstawicieli różnych pokoleń. Słowo konfrontacja nie jest tu zresztą najzręczniejsze, chodzi bowiem bardziej o porównanie różnych punktów widzenia z perspektywy doświadczeń wieku dojrzałego i na samym progu dorosłego życia[8].

Cień już niedaleko i Pamięć to pytanie o miejsce Nowej Huty w życiu ludzi, różnych pokoleń. W jaki sposób to miejsce wyznacza życie ludzi, w jaki sposób genius loci wpływa na postawy i zachowania dawnych i młodych pokoleń. Po raz kolejny warto wrócić na chwilę do znakomitego filmu Kosińskiego. Szczepan Brzeziński wspomina swoją pracę w Nowej Hucie. Kosiński wspomnienia Brzezińskiego, mówiącego o tyfusie, smrodzie, nadużywaniu alkoholu, braku maszyn, nieufności czy wręcz wrogości miejscowych, odrzuceniu przez Kraków, ilustruje fragmentami dawnych kronik i ówczesnych pieśni. Kontrast jest oczywisty, ale na nim sens filmu się nie wyczerpuje. Szczepan Brzeziński mówi bowiem wyraźnie, że Nowa Huta to jego miejsce, w przeciwieństwie np. do Krakowa. Najchętniej zburzyłby Kraków, zostawiając jedynie Starówkę i wybudował to miasto na nowo, jak Nową Hutę, z szerokimi ulicami i zielenią. Zupełnie inaczej podchodzi do sprawy jego syn, dla którego liczy się właśnie Kraków, a Nowa Huta nie jest w stanie nic mu zaoferować.

Budowałem miasto to również film o ojcu i synu, o dwóch pokoleniach i relacjach między nimi. Rozkład racji między nimi także podobny. Ojciec budował Nową Hutę i jest dumny z miasta, podziwia także jego architekturę, synowi bliższy jest Kraków. To dwa pokolenia: budowniczych i ich synów, którzy zakwestionowali dorobek ojców. Powstanie filmów Kosińskiego i Karabasza dzieli kilkanaście lat, tymczasem można odnieść wrażenie, że pewne kwestie pozostały niezmienne. Widać natomiast, że poczucie zniechęcenia wśród młodych $\mathrm{z}$ czasem stawało się coraz większe.

Nowa Huta, tak jak była świadectwem wiary w przyszłość, tak stała się symbolem upadku wiary w przeszłość. Mit założycielski Nowej Huty nie oddziaływał na jej nowe pokolenia, dla nich nie stanowiła ona części przeszłości, a więc także tożsamości. U Karabasza pamięć o Nowej Hucie, jej początkach, towarzyszy starszemu pokoleniu. Z tą pamięcią związane są również emocje i wartości. Rozczarowanie, które towarzyszy dawnym pracownikom, związane jest także m.in. $z$ upadającym etosem pracy. Dla Józefa czy też jego przyjaciela Leona Nowa Huta ma jeszcze wymiar symboliczny[9].

[8] M. Hendrykowska, Patrzeć intensywnie. O filmach Kazimierza Karabasza, w: Klucze do rzeczywistości. Szkice i rozmowy o polskim filmie dokumentalnym po roku 1989, red. M. Hendrykowska, Wydawnictwo Naukowe UAM, Poznań 2005, s. 112.

[9] Józef ma w Nowej Hucie jeszcze jedną sprawę do załatwienia. Kilka lat temu wyprowadził się 
Dla tych, którzy pozostali w Nowej Hucie i przepracowali tam ponad trzydzieści lat, miejsce to było elementem również ich prywatnej pamięci, która stała się częścią ich dzisiejszej tożsamości. Dla młodych zmityzowane początki Nowej Huty nie mają znaczenia, nie istnieją w ich świadomości bądź są z niej wypierane, jako coś, co w gruncie rzeczy utrudnia życie. Nie ma w nich pamięci, która pozwoliłaby nadać sens dzisiejszemu bytowaniu. Dlatego są gotowi uciec, tak jak syn Szczepana Brzezińskiego. Zresztą trzeba pamiętać, że Józef też kiedyś wyjechał, opuścił Nową Hutę z przyczyn osobistych. Tylko że pamięć Nowej Huty jest w nim cały czas obecna. Jeśli Heniek wyjedzie, Nowa Huta nie stanie się w tak wyraźny sposób częścią jego tożsamości. Dla Józefa sens Nowej Huty zawarty jest w jego prywatnym doświadczeniu.

Heniek Wenda jest na pograniczu. Mieszka i pracuje w Nowej Hucie - choć nie w kombinacie - bo gdzieś trzeba. Czy jeśli straci mieszkanie po ojcu, coś go tu zatrzyma? Nie przypadkiem Cień już niedaleko jest filmem czarno-białym. Dzięki temu Karabaszowi udało się osiągnąć poczucie szarości i nijakości miasta. Nie ma w nim nic wyjątkowego. Jeśli wnikliwie przyjrzeć się tym filmom, to uwagę zwraca od razu brak Nowej Huty jako zjawiska architektonicznego. Prawie niewidoczne budynki pojawiają się niejako w drugim planie. Samo miasto jest brzydkie, brudne i szare, nieciekawe. Brzydkie miasto z brzydkimi mieszkaniami[10]. Ulewny deszcz wzmaga jeszcze to przygnębiające wrażenie.

Dla nowego pokolenia praca w Hucie nie jest już wyznacznikiem awansu społecznego.

stąd, swoje mieszkanie pozostawiając synowi. Okazało się jednak, że mieszkanie jest w gestii kombinatu, a syn powinien je opuścić. Józef nie przyjmuje tego do wiadomości, zarzucając urzędnikom brak zrozumienia dla idei, które kiedyś towarzyszyły Nowej Hucie.

[10] B. Janicka, Cień szarego człowieka, „Film” 1986, nr 3, s. 9.

[11] Por. M. Przylipiak, Paradoksy paradokumentalizmu, „Kino” 1986, nr 9, s. 2.
Ślad tej postawy znajdziemy już w pierwszej rozmowie ojca z synem. Syn mówi, że bierze dwa razy więcej nadgodzin, niż pozwalają przepisy. Pracy jako specyficznej kategorii czy też wartości nadawane są inne znaczenia. Syn nie jest w stanie zarobić tyle, żeby wyżywić rodzinę. Musi pracować ponad miarę. Motyw pracy i wynagrodzenia, również we wspomnieniach, powraca kilka razy, czasem gdzieś w tle. Etos pracy prezentowany przez Józefa, jego niezgoda na drobne przekręty, dla dzisiejszego widza są nieco archaiczne, ale takie były już także dla syna bohatera.

Kulminacją filmu Cień już niedaleko jest rozmowa Józefa z przyjaciółmi jego syna[11]. Fakt umieszczenia tej rozmowy na końcu utworu nadaje jej szczególne znaczenie. Ważne są również jej okoliczności. Heńkowi urodził się drugi syn, na świat przychodzi kolejne pokolenie. To dobra okazja, by dokonać rozliczenia z przeszłością.

Jeden z przyjaciół Heńka pyta Józefa, czy ten naprawdę nie żałuje. Czego, pyta zdziwiony Józef. „No, tych straconych lat. Naharowaliście się i co z tego wyszło? No właściwie nic”. Józef zaczyna tłumaczyć, że „w kraju wyniszczonym przez wojnę zaczęło się budować i ludzie zaczęli żyć”. Czy jednak argumenty sprzed kilkudziesięciu lat, nie odmawiając im nawet ważności, mogą przekonać kolejne pokolenie? Czy „nie widzi pan różnicy między tym, co ludzie włożyli, na co mieli nadzieję, a tym, co wyszło?”. To nie różnice, to przepaść, mówi inny młody mężczyzna. Te pytania podważają to wszystko, co stanowi o pamięci Józefa. Nie może się tego wyprzeć, ponieważ niezależnie od wszystkiego, podważyłby sens całego swojego życia.

Rozmowie towarzyszą wyświetlane akurat w telewizji dawne kroniki, po raz kolejny pokazywane w filmie. Młodzi mówią, iż mają odwage mówić głośno, a za czasów Józefa nie zawsze tak było. „Przepraszam, że tak mówię, ale ja się boję, że wam, panowie, często wystarczyły po prostu gołe hasła, w które uwierzyliście. A właściwie daliście się nabrać na nie, bo jak to nazwać”. Młodzi atakują Józefa, że tamto pokolenie nie walczyło, nie stawiało oporu. Józef mówi, że 
wówczas widzieli, że nie wszystko idzie tak jak powinno, ale coś się działo. „Co panu tak naprawdę zostało?” „Cholerną satysfakcję. Że coś serio zrobiłem. Choćby nie wiem jakim kosztem. I to jest i pracuje. Poza tym mam kupe wspomnień. I to nie do zatarcia”. Czy jednak wspomnienia to wystarczające? Kilka razy w filmie padają słowa: „Było, minęło”, wypowiadane zresztą przez reprezentantów różnych pokoleń.

Słowa przyjaciół Heńka są oskarżeniem wobec pokolenia, które zbudowało ich przestrzeń życia. Oczywiście, nie Józef i jego koledzy są winni. Po prostu w ten sposób film mówi o stosunku młodego pokolenia wobec rzeczywistości uformowanej przez Polskę Ludową. Nowa Huta jest symbolem rozczarowania Polską. Widać zresztą w tym filmie echa zniechęcenia młodych ludzi w połowie lat 8o. Nowa Huta budzi ich złość, ponieważ oni szczególnie mocno widzą rozdźwięk między obietnicami złożonymi pokoleniu ich ojców a warunkami, w których żyją oni sami. Ponieważ w latach 50. Nową Hutę uczyniono symbolem obietnic Nowej Lepszej Polski, musiała też stać się symbolem rozczarowania (jak wskazuje film Kosińskiego, stało się tak już wcześniej).

Interesująco przedstawiona jest postać syna. Akceptuje on argumenty przyjaciól, jednocześnie w jakiś sposób rozumie ojca. W przeciwieństwie do Józefa i Leona, Heniek i jego koledzy to ludzie z Nowej Huty, ale nie Nowej Huty. Miejsce zamieszkania nie ma tu nic do rzeczy. Życie Józefa zostało natomiast przez Nową Hutę dookreślone i przez nią uformowane. Różnice pokoleniowe, będące jednym $z$ tematów filmu, zostają określone również przez stosunek do Nowej Huty. Jego końcowe fragmenty wydają się być rozpisanym na głosy rozwinięciem ostatnich fragmentów filmu Budowałem miasto.

W Pamięci Karabasz pokazuje ludzi, którzy kilkadziesiąt lat wcześniej mieli stać się Nowym Człowiekiem. Odnalazł dwóch z trzech bohaterów filmu Romana Banacha Na wielkiej budowie z roku 1953, ukazującego losy chłopców z podhalańskiej wsi. Film Banacha miał pokazywać, jak wraz z Nową Hutą rosną nowe kadry Polski Ludowej. Karabasz zaprosił An- toniego Zaleśnego i Józefa Kasprzyka i pokazał im film, którego byli bohaterami. Ich pierwsza reakcja po projekcji wskazuje na trwałą obecność tamtych lat w ich pamięci. „Mogłyby się te lata wrócić”. „Tak było”, mówi Kasprzyk. Przyjmują film Banacha jako autentyczny zapis ich ówczesnego życia i poglądów.

Mamy zatem do czynienia $z$ ochroną własnej pamięci. Być może opartej na zmistyfikowanych przesłankach, ale osobistej i w ten sposób autentycznej. W Pamięci nawet te wspomnienia, które dotyczą najgorszych fragmentów historii Nowej Huty, nabierają nostalgicznego charakteru, ponieważ są związane z cząstką tożsamości tyleż zbiorową, ile indywidualną. Gdyby bohater Cienia... chciał odpowiedzieć młodym na pytanie, czy było warto, mógłby posłużyć się słowami licznych postaci, które w Pamięci przywołują swoje wspomnienia[12]. Zapewne wiele autentycznych wydarzeń zatarło się, a ówczesne doświadczenia czytane są z perspektywy lat i późniejszych wydarzeń. Nie zmienia to jednak faktu, iż pamięć i tożsamość bohaterów Pamięci zostały ukształtowane przez Nową Hutę.

3.

Początki Pamięci sięgają w przeszłość. Słowa padające w przemówieniu Franciszka Jóźwiaka, w połowie lat 50. członka Biura Politycznego PZPR, nie pozostawiają wątpliwości. Huta miała być symbolem socjalizmu, nowej rzeczywistości, nowego życia, Nowego Człowieka. Dlatego też otrzymała imię Lenina, które miało być dla niej wyróżnieniem i wyzwaniem. Nowa Huta miała być dziełem wiekopomnym, które będzie kształtować całe pokolenia. Kolejne ujęcia przenoszą nas do roku 1984. Przed kamerą pojawiają się ludzie, pytani na ulicy, co mogą powiedzieć o początkach Nowej Huty. Pamięć się zaciera, słyszymy z offu. Padają co prawda stwierdzenia, że musiało być to ważne wydarzenie, ale nie wynikają one z przekonania i doświadczenia wypowiadających się osób.

[12] Por. M. Jazdon, Kino dokumentalne Kazimierza Karabasza, Wydawnictwo Naukowe UAM, Poznań 2009, s. 211. 
Oglądamy stare kroniki, Nowa Huta ze zdjęciami Władysława Forberta i Olgierda Samucewicza. W pewnym momencie komentarz znika, pozostaje tylko obraz. Zdjęcia z przeszłości nabierają nowych znaczeń. Charakterystyczna dla socrealizmu nadobecność słowa, a w tym przypadku także muzyka (pieśni marszowe), narzucały widzowi sposób odbioru. W polskiej kulturze stalinowskiej w obrazach Nowej Huty $\mathrm{z}$ trudem pojawiało się miejsce dla jednostki. Nie konkretni robotnicy, mimo że padały nazwiska, byli bohaterami nowohuckich opowieści, lecz sama Nowa Huta jako swoisty byt społeczny i polityczny lub też idea pracy lub nowoczesności. Wielki piec ruszył, emocjonowały się kroniki filmowe. Tymczasem w zakończeniu Pamięci od żywej i entuzjastycznej kroniki, koncentrującej się na maszynach i oficjelach, Karabasz przechodzi do zwolnionych ujęć, też pochodzących z ówczesnych kronik, ale przyglądających się ludziom.

Kiedy kamera pokazuje twarze ludzi, którzy po latach oglądają archiwalne zdjęcia $z$ budowy Huty, można zastanawiać się, na ile ich pamięć jednostkowa sprzęgła się z pamięcią oficjalną, zapisaną choćby w kronikach i ówczesnych komentarzach. Jak również - na ile tamte zdjęcia i słowa stały się częścią ich pamięci. Filmy Karabasza pokazują nieoczywiste pogranicze między oficjalną i prywatną pamięcią, przypisaną w dodatku i pokoleniom, i jednostkom. Oficjalną zewnętrzność z prawdziwymi marzeniami Karabasz konfrontował już wcześniej, chociażby w zrealizowanym w latach 60 . Na progu. Filmy Cień już niedaleko i Pamięć są zatem konsekwentnym nawiązaniem do motywów i postaci, które towarzyszyły reżyserowi od kilkudziesięciu lat.

Pamięć rozpoczyna się od ujęcia przedstawiającego człowieka zakładającego film na stół montażowy. Kiedy w Cieniu... znajdujemy się

[13] Warto też wspomnieć nakręcony już po Pamięci, w roku 1988, piękny film Ireny Kamieńskiej Dzień za dniem, w którym konfrontowała współczesny dzień ciężko pracujących kobiet z pamięcią o ich młodości - dawnych czasach radosnego rozkwitu socjalizmu. na zebraniu, dominującym elementem tej sekwencji jest kamera filmowa, zwracająca uwagę na wage wizualizowania Nowej Huty. Obecność dziennikarzy staje się również symbolem rytualizowania większości kwestii związanych z Nową Hutą. Sposób filmowania w pewnym momencie zaczyna przypominać kronikę filmową. Oficjalne i jednostkowe przeplata się cały czas. Karabasz ma świadomość, że inaczej Huty pokazać nie można.

W Cieniu... to, co związane $\mathrm{z}$ ideologią, jest sztuczne. Dotyczy to samego miasta, ale i orderów, i telewizji. Miasto staje się prawdziwe dzięki swoim mieszkańcom. Prawdziwa jest bowiem codzienność, niezależnie od tego, że bywała przez ideologię przefiltrowana. Karabasz pokazuje, jak to, co oficjalne, zamienia się w to, co prywatne. Kiedy Józef odwiedza swojego przyjaciela, Leona, oglądają zdjęcia. Wspominają dawnych kolegów, którzy trzydzieści lat wcześniej razem z nimi pracowali w Nowej Hucie. Ta scena, skromna, zostaje przeciwstawiona oficjalnej imprezie i kronikom. W rozmowie padają imiona, kilka słów o dalszych losach poszczególnych postaci.

Karabasz nawiązuje w jakiś sposób do pytań, które stawiali w latach 70. Krzysztof Kieślowski (Murarz) czy Wojciech Wiszniewski (Wanda Gościmińska. Włókniarka, Opowieść o człowieku, który wykonat 552\% normy). Oprócz zwyczajnej - chciałoby się rzec: karabaszowskiej - opowieści o człowieku, pojawia się kwestia ludzi, którzy kiedyś budowali zręby nowego systemu[13]. Pytanie, co z nimi dzieje się dzisiaj, co dał im tamten czas, nie w sensie politycznym, ale czysto ludzkim. U bohaterów Kieślowskiego i Wiszniewskiego duma łączyła się $\mathrm{z}$ rozczarowaniem. Dobrym przykładem ukazującym szczególne punkty wspólne tego, co oficjalne, i tego, co prywatne, jest Człowiek $z$ marmuru. Mateusz Birkut próby bicia rekordu w układaniu cegieł nie traktuje jako czegoś narzuconego z góry. Jest w nim autentyczny entuzjazm, który dopiero później, pod wpływem kolejnych doświadczeń Mateusza, przerodzi się w gorzką świadomość robotnika pozbawionego złudzeń. Jestem w stanie wyobrazić sobie boha- 
tera Cienia... jako inny wariant życia Mateusza Birkuta lub jego kolegów. Bez dramatycznych wydarzeń jeszcze w latach 50., natomiast $\mathrm{z}$ bolesnym doświadczeniem przemijania określonych systemów wartości.

W obrazie Cień już niedaleko podczas przemowy ministra, wspominającego uruchomienie wielkiego pieca, podkreślającego, jak wielką rolę odegrała Nowa Huta, kamera pokazuje twarze zebranych, zatrzymując się na nich sekundę dłużej niż powinna (w ten sam sposób Karabasz montuje scenę, w której uczestnicy uroczystości oglądają archiwalny film o Nowej Hucie). W ten sposób Karabasz przedstawia dwie historie Nowej Huty: oficjalną, zbiorową, oraz indywidualną, składającą się z tysięcy życiorysów, często nietworzących zwartej całości. Słowa zostają skonfrontowane $\mathrm{z}$ obrazem. Minister posługuje się okolicznościowymi sloganami. Część z nich jest oczywiście fragmentem wspomnień dawnych pracowników. Minister w pewnym momencie zaznacza, że nie jest tu po to, aby wygłaszać referat, lecz by podziękować budowniczym Nowej Huty. Ten element jego wystąpienia także należy do swoistego rytuału. Tak naprawdę w oficjalnym tekście jednostka znajduje się na drugim planie, o czym boleśnie przekona się Józef.

Józef Wenda (Mariusz Dmochowski) to człowiek spełniony i niespełniony zarazem. Przyjeżdża ze Szczecina do Nowej Huty, aby jako budowniczy Pieca nr 1 - odebrać odznakę "Zasłużony dla kombinatu Huta im. Lenina”. Trzydzieści lat wcześniej, 22 lipca 1954 roku, popłynęła pierwsza surówka $z$ pierwszego wielkiego pieca. Z okazji rocznicy do Nowej Huty zostają zaproszeni pracownicy, którzy przed laty brali udział w początkach funkcjonowania kombinatu. Józef jednak nie otrzyma odznaczenia. Na przeszkodzie staną dawne zaszłości. Wenda czuje się zraniony. Dla niego, podobnie jak dla innych robotników, uroczystość jest czymś więcej niż rytuałem. Oczywiście, nie chodzi o odznaki zasłużonego pracownika, choć i one mają dla nich wartość. Adresatem tego pytania zdaje się być cała peerelowska rzeczywistość. Czy oczekiwania, jakie niosła ze sobą budowa Nowej Huty, ale także innych znaczących budów, zostały zrealizowane, nie tylko w odniesieniu do jednostek, ale całego społeczeństwa?

Przypomina się w tym momencie film Wiszniewskiego, który odsłaniał fikcję sloganów ukazujących sensowność ówczesnych działań. Hasła głoszone współcześnie przez Wandę Gościmińską, odpowiadającą na pytania młodych, brzmią sztucznie. Oni pytają jak na akademii, ona im w ten sam sposób odpowiada. Pamięć oficjalna to przede wszystkim rytuał. Odpowiedzi nikogo nie obchodzą, zamiast uważnego słuchania mamy oklaski.

Tamte znaki zapytania wracają u Karabasza. Nowa Huta była wielką inwestycją gospodarczą i polityczną. Filmy Karabasza opowiadają o tym, co z niej zostało. Nie w bilansie ekonomicznym i propagandowym, ale czysto ludzkim. Czy wspomnienia to aż tak mało? Czym dla budowniczych Nowej Huty jest pamięć? Czym była budowa Nowej Huty nie dla państwa, gospodarki, socjalizmu, ale dla ludzi, którzy ją budowali, oddając jej najlepsze lata swojego życia? Czy ich ofiarność została doceniona?

4.

Nowa Huta jest elementem tak silnie obecnym w uniwersum symbolicznym kultury peerelowskiej, a w jakimś stopniu także postpeerelowskiej, że właściwie nie sposób potraktować jej jako czynnika neutralnego znaczeniowo. Historie rozgrywające się w Nowej Hucie mogłyby w zasadzie wydarzyć się wszędzie. Gdyby jednak usytuować je w miejscu mniej symbolicznym, miałyby inne znaczenie. Nowa Huta stanowi przestrzeń na tyle znaczącą, że sytuuje życie bohaterów w dodatkowych kontekstach. Rozczarowanie młodych pokoleń widać tak wyraźnie, ponieważ jest pokazane na tle budowanego kilkadziesiąt lat wcześniej entuzjazmu. Dodatkowo pada pytanie o charakter ówczesnego entuzjazmu: czy był prawdziwy, czy stanowił wartość dodatkową, wykreowaną na potrzeby ówczesnej propagandy. Postawy starych robotników, którzy pracowali w Nowej Hucie od początku, uniemożliwiają udzielenie prostych odpowiedzi 
na to pytanie. Dotyczy to zarówno Józefa w filmie Cień już niedaleko, jak i bohaterów Pamięci.

Karabasz zadaje w tych filmach pytanie o sens pamięci, zarówno oficjalnej, jak i jednostkowej. Opisuje zetknięcie dwóch pamięci, ich miejsca wspólne i osobne. Pokazuje prywatną, należącą do bohaterów, historię Nowej Huty, ale jednocześnie udowadnia, że prywatność i oficjalność wchłonęły się nawzajem. Nowa Huta jest miejscem, w którym pamięć oficjalna i jednostkowa są nierozerwalnie związane. Budowa Nowej Huty była wynikiem propagandowej inspiracji. Karabasz dostrzega jednak coś więcej. W tę budowę byli zaangażowani ludzie. Zapewne byli częścią propagandy, z kolei hasła propagandowe wtopiły się w nich samych, zyskując tym samym swoistą autentyczność.

W filmach Kazimierza Karabasza Nowa Huta jest tłem dla opowieści o zwyczajnych ludziach, ale tłem znaczącym, które określa ich miejsce w życiu zarówno w przeszłości, jak i teraźniejszości, niezależnie od tego, czy czują się z nią związani, czy też się przeciw niej buntują. Bohaterowie Karabasza byli ludźmi z Nowej Huty. Budowali ją, pracowali w niej, mieszkali. Są tak- że ludźmi, których ta budowa chcąc nie chcąc uformowała. Niezależnie od oficjalnej recepcji tej budowy, ona w nich pozostanie. Są zatem także ludźmi Nowej Huty. Nie wymażą swojej pamięci. Spod oficjalnych zdjęć, filmów, dawnych i rocznicowych przemówień, u Karabasza zawsze widać człowieka. Dla tych ludzi Nowa Huta stała się nieodłączną częścią pamięci.

Filmy Karabasza nie są pochwałą Nowej Huty, nie stanowią też rozliczenia z jej przeszłością (w takim sensie jak choćby Zagubione uczucia lub Człowiek z marmuru). Nawet jeżeli pojawiają się opowieści o negatywnych elementach historii tego miejsca, są po prostu częścią pamięci. Filmy te pokazują jednakże, że nawet w opowieści o zwykłym szarym człowieku Nowa Huta będzie zawsze miejscem mającym jakieś dodatkowe znaczenie, wpływające na swoich bohaterów, zarówno przez to, czym miała być, jak i przez to, czym się ostatecznie stała/nie stała. I pokazują, że nie ma jednego jej wymiaru. Są ludzie, którzy traktują ją jako zwykłe miejsce, ale są też tacy, których ukształtowała. Ludzie Nowej Huty i z Nowej Huty.

\section{Między powieścia a adaptacja - kilka spostrzeżeń $z$ perspektywy widza}

\author{
JUSTYNA SULEJEWSKA \\ Uniwersytet im. Adama Mickiewicza
}

Adaptowanie tekstów literackich na medium filmowe jest sztuką równie sędziwą jak X muza. Można by przypuszczać, iż ponadstuletnia obecność zjawiska będzie szła w parze $\mathrm{z}$ jego lepszym rozumieniem, oswojeniem; byłoby to widoczne przede wszystkim na gruncie refleksji teoretycznej, wskazującej i tłumaczącej powszechne zabiegi służące adaptacji, omawia-

[1] A. Helman, Wstęp, w: eadem, Twórcza zdrada. Filmowe adaptacje literatury, Ars Nova, Poznań 1998, s. 8. jącej ich ewolucję ze względu na zmiany technologiczne lub kulturowo-społeczne. Alicja Helman, referując dzieje rozważań nad relacją filmu do literatury, podkreśla jednak, że stworzenie normatywnej teorii przekładu lub nawet opisanie i wymienienie wszystkich możliwych modeli ekranizacji jest przedsięwzięciem niemożliwym. Sposobów adaptacji jest, „chciałoby się rzec, że nieomal tyle, ile jest powieści do sfilmowania lub co najmniej tyle, ilu jest reżyserów przenoszących literaturę na ekran" [1]. I choć badaczka zaraz dopowiada, iż podobne 